\title{
JESSIE LOUISA WHITMAN: \\ Memories of Uncle Walt, et al., 1939-1943
}

\author{
RANDALL WALDRON
}

In their Introduction to Dear Brother Walt: The Letters of Thomas Fefferson Whitman, Dennis Berthold and Kenneth Price quoted briefly from a 1939 interview in which "Jeff's" daughter, Jessie Louisa, provided some details about the background of her mother, Martha Mitchell ("Mattie") Whitman: "she was an orphan, her father who had married a second time being dead. Her stepmother was her guardian and while mother was a minor, had charge of her money, which amounted to several thousand dollars. [When] Mother announced to her her intentions of marrying father after she came of age .... the stepmother skipped out with all the funds, simply vanished, and mother was left penniless." This information was most welcome, for I had been able to say very little, in my edition of Mattie's letters some years earlier, about her life before she married into the Whitman family, and could only speculate on what was here confirmed: that she had been an orphan whose connections with kin had been largely if not entirely severed. ${ }^{2}$ The interview in which this small but helpful revelation comes is the most interesting part of the little-noticed Fansler Collection of Whitman materials at Northwestern University. ${ }^{3}$ The forty-eight page handwritten transcript, supplemented by a number of Miss Jessie's letters to the interviewer, constitutes an extensive record of memories and feelings about Whitman, his family, and some of his associates, carried down four decades into our own century by a close relative who knew and loved the poet well. The memories are sometimes faulty or confused, and the feelings colored by insistent family loyalty that may occasionally distort the truth, but in the aggregate they amount to a notable addition to the fund of Whitman biographical information. The interview and letters also significantly flesh out the heretofore shadowy figure of Jessie Whitman, revealing a woman of considerable substance and character, much of whose personality appears to have been a function of her identification with her famous Uncle Walt.

The Fansler Collection was given to Northwestern in the 1940s by Ralph L. Fansler, a passionate Whitman enthusiast, indefatigable bloodhound on the trail of Whitman facts and ephemera, and author of 
The Password Primeval, an unpublished life of the poet. ${ }^{4}$ Fansler's relationship with Jessie Whitman was rather unusual. Berthold and Price identify the person who interviewed her in 1939 as Garrett Newkirk, inasmuch as the record of the conversation is headed "Interview with Jessie L. Whitman, reported by Garrett Newkirk." This was, however, a pseudonym impulsively taken by Fansler some months before he came to see Miss Whitman, if we are to credit the rather extraordinary account he gave her upon confessing his true identity some years later:

The name "Garrett Newkirk" was selected because of it having at least a hidden spiritual significance, viz:

Garrett-garret-attic-upper room

Newkirk-new church

When I went to Camden for the first time in February 1939 I was imbued with the idea that Walt Whitman had a hope that the poems he so laboriously worked on in his attic bedroom in Brooklyn, like the founding of the Christian Church in the upper room at Jerusalem, would help to create a new church of Universal Brotherhood. I still am very confident of such being his motivating force.

I was at 330 [sic] Mickle Street for over three hours and Mrs. Davis [the curator] did most of the talking. Occasionally I'd get a word in edgeways, and somehow she gained the idea that I was some sort of an expert on Walt Whitman, and she told me that I knew so much that thereafter she was going to refer anyone whose questions she couldn't answer to me. The Newkirk subterfuge was thought up on the spur of the moment when I signed the guestbook for I intended to shield myself from a lot of people who would fire at me a lot of questions they were too lazy to look up for themselves. 5

Fansler goes on to say that his wife opposed the use of the pseudonym in his dealings with Miss Whitman, but doesn't explain why he chose to do so over her objection. Whatever the justification may have been, he introduced himself as Newkirk in his first letter to her in March 1939, and it was as Newkirk that he appeared at her apartment door in Saint Louis for the interview the following October. This curious deception continued for three years, during which time Fansler wrote cordial letters to Miss Whitman and visited her on at least a couple of other occasions. When advancing age obliged her to move from her apartment to a hotel, he even allowed her to give him her collection of Whitman books, letters, photos and other memorabilia-still believing him to be Garrett Newkirk. Only after making these items the heart of a Whitman exhibition at the Detroit Public Library in March 1942, did he write his letter explaining the "subterfuge" and apologizing fulsomely for having "sailed under false colors," especially in accepting the gift of her Whitman treasures. Fansler concluded this letter by suggesting that he hoped someday to be recognized as a Whitman authority and as such to turn the material over to Northwest- 
ern, if that met with her approval. Happily, he did not wait for such recognition to come (it never did), but having received Miss Whitman's permission to dispose of the items as he saw fit, presented them to the university straight away, in September $1942 .^{6}$

Although-as we will see-the "Newkirk" interview and her letters make it clear that Jessie Whitman was not immune to being offended or angered by what she considered unfair or duplicitous behavior, she appears not to have taken umbrage at Fansler's protracted misrepresentation of himself or at his so hastily letting go her generous gift to him. A friendly correspondence continued between them during the remainder of 1942 and 1943, with Mr. and Mrs. Fansler sending her birthday and Christmas presents. The last of her letters, responding to "pleasant and chatty" ones received from them, is dated November 11, 1943; whether she wrote to or heard from them after this is not known. Mrs. Rudolph Blome, who became her nurse and companion in the late forties, reports that sometime around 1945 Miss Whitman's lawyer and a friend, Mary Taylor, had her committed to a sanitarium, ostensibly to protect her from an attempt to get her money, of which she had inherited quite a great deal from her father and her uncle George Washington Whitman. It is not unlikely that such a radical shift in circumstances brought an end to her correspondence with the Fanslers.

Jessie Louisa Whitman and her older sister Manahatta ("Hattie") were born in the house on Portland Avenue in Brooklyn that their parents shared with Walt, his mother, and brothers George and Edward. Though the Jeff Whitman family moved to Saint Louis in 1868, when Hattie was seven and Jessie four, both girls continued to be much loved by, and themselves strongly attached to, their Uncle Walt. Their mother having died in 1873, the sisters went east to school in the late 1870 s and early 1880 s, spending much of each summer at the home of George Whitman in Camden, where Walt was also living at that time. After Hattie's untimely death in 1886, Jessie stayed in close touch with Walt in the years that remained to him, and visited him frequently in his final months. The Fansler interview reveals that subsequently Jessie maintained her connections with the family in the east, at least until the death of George in 1901. After that she disappears from view until the late nineteen twenties and early thirties, when she provided information to Clifton J. Furness and Clara Barrus for their books on Whitman. Mrs. Blome reports that Miss Whitman had been to Europe several times, which trips undoubtedly took place prior to the Fansler interview, inasmuch as the beginning of the war would have made travelling there unlikely by 1939 .

The interview presents a colorful picture of seventy-six year old Jessie rummaging around in her apartment amidst her trove of Whitman treasures-presentation copies of the poet's works on the shelf, family 
photos and letters in a dining room cabinet, Walt's will and codicil in a drawer in the bedroom. It also tells us a good deal of the kind of woman she was, a subject about which we have known very little. From sketchy evidence in the letters of her uncle Walt, her grandmother Whitman, and her parents - as well as from a few unpublished youthful letters of her own and of her sister-we gather that Jessie was a healthy and it seems rather bright little girl. At seven she was taking piano lessons, and could write legible and coherent notes to Grandma and to Uncle Walt, one of them thanking him for the gift of a book: "I got the book that you sent me, and $i$ can read it and it is a very nice Book. I thank you very much for sending it to me. i look out for it it makes me so happy when papa brings it up i want you to send me another book this week. . . ."7 In her only other known letter to the poet, written from Hartford, Connecticut in 1888, she reported in bright, chatty tones of having visited friends, first in New York, then in Hartford, and enjoying it all immensely. She had been to an art exhibit and declared, "looking at beautiful pictures and having good music are my chief pleasures with of course reading added the last-a thing we could hardly exist without."8 Uncle Walt must have been gratified by her love of music, which he shared, and of course by the value she placed on reading.

That this value remained with her is one aspect of Miss Jessie's adult personality made clear in the Fansler interview and letters. Whether there was medical justification for sending her to a sanitarium in the mid-1940s remains unknown, but her mind appears to have been alert, clear and inquisitive in 1939 and the early 1940s, as evidenced best by her reading. She read, if not in a scholarly or intensely intellectual way, nevertheless a great deal and rather eclectically-newspapers, the Literary and Reader's Digest, the Saturday Review, and books of various kinds borrowed from the Mercantile Library (which, incidentally, is where Walt had gone to read almost daily during his lengthy visit with Jeff, Jessie and Hattie in 1879). In a letter to Fansler, after she had moved from her apartment into the Fairmont Hotel, Miss Whitman lamented being without her books, especially the encyclopedia, which she had used to better understand the war news. In spring 1943 Fansler sent her a Rand McNally atlas to supply that need, and in thanking him for it she wrote of her "weakness" for geography, and of always having studied the maps of places she visited on her trips. Walt Whitman would have been pleased by her love of geography, which also interested him greatly. ${ }^{9}$ Gratifying to him as well would have been his niece's knowledge of and feeling about critical and scholarly literature concerning himself. She had a good general acquaintance with the standard works about him (especially the biographies), and decided preferences among them. 'Furness' 'Walt Whitman's Workshop' gets the closest of 
all to my Uncle," she told Fansler, adding that she also liked Cameron Rogers' The Magnificent Idler. ${ }^{10}$ She was much interested in keeping up with new work on Walt as well. In early 1943, for example, she read some pieces by Henry Seidel Canby in the Saturday Review, from which she learned of his forthcoming book on the poet, and determined to read it as soon as it came in at the Mercantile. One night on her favorite radio program, "Information Please," Miss Jessie heard Clifton Fadiman and Christopher Morley talking about a book on Whitman by the South African statesman Jan Christian Smuts. Having read and liked several war-related articles by him in the newspaper, she declared in a letter to Fansler the next day that she would ask for that book in the library as well. This was on June 22, 1943, five days before her eightieth birthday, at which age Miss Whitman seems to have been a bright, engaged, and vital woman indeed.

Though Jessie Whitman was thus an interesting person in her own right, more interesting is what she said and wrote to Fansler about other members of the Whitman clan and about Walt himself. The faithfulness of her lifelong attachment to and interest in her famous uncle was matched by her insistence on denying certain unattractive representations of the family that had been established by biographers. "Oh I get so tired of reading all the balderdash that comes out about us Whitmans," she exclaimed during the interview. One matter she considered balderdash was the image of the family matriarch, the poet's mother, as a woman who-in Jessie's indignant summary of the collective indictment- "Had to be written down to because she was uneducated and almost illiterate." As evidence against this charge she showed Fansler a letter written to her father Jeff by grandmother Whitman when Jessie's mother died. Like all of Louisa Van Velsor Whitman's letters, this one (which Fansler copied into the transcript of the interview) is characterized by faulty syntax, punctuation, spelling and mechanics; but it is reasonably coherent and clear in its honest, simple expression of strong feeling, reading in part: "O Jeffy is she gone. to me it seems almost impossible. almost every thing I put on reminds me of her goodness to me. [Mattie, a seamstress, had made many of Mrs. Whitman's clothes.] she has many sincere mourners. . . . Martha's death has been a great blow to [Walt] but Jeffy dear we must all hope for the best and try to be calm in our affliction." When Fansler had read this, Jessie looked at him "keenly, her blue eyes, although somewhat faded, flashing, and asked, 'Does that letter show any illiteracy about it?" - to which question Fansler quickly responded in the negative. It is true of course that Mother Whitman was not "literate" in the sense of having wide knowledge or learning, nor in being a technically correct writer. But if part of literacy is the ability to write well enough to effectively communicate 
meaning and emotion, Miss Jessie seems justified in maintaining that her grandmother had not been illiterate.

She was even more adamant in refuting the suggestion, common to most Whitman biographies, of inherent mental disease in the family. She stoutly denied any insanity in either of the two Whitman brothers who clearly did suffer from some kind of mental impairment-Jesse, the eldest, whose long-term neurosis became so violent in his mid-forties that Walt personally committed him to an asylum; and Edward, the youngest, who was retarded and crippled in both hands and one leg. The question here is whether the conditions of these two brothers betrayed a possible inherent weakness in the Whitman blood, or can be explained in other terms. A couple of brief glimpses of Miss Whitman's position on the issue have appeared previously ${ }^{11}$ but in the interview we find her defense of her uncle's and of the family's soundness of mind stated much more fully and vociferously. "[Those] fantastic tales about Uncle Jesse and Eddy," she huffed, "one a lunatic and the other an imbecile, trying to explain it as being caused by a vascular weakness in the family. There never was the slightest taint of insanity in any member of the family. ...." Eddy, she went on, "was a perfectly normal baby, and exceptionally well until about three years old, when he had a bad case of scarlet fever after which his mind became clouded somewhat. . . . A few years later [he] had infantile paralysis. He limped badly afterwards, and his hands were drawn in." This account of Eddy's condition was of course secondhand to Miss Jessie, who wasn't born until he was a grown man, but she added her own recollection of his being trusted to take her and sister Hattie, as little children, on long afternoon excursions in a pushcart, always returning safely "without any of the older folks being alarmed."

Of Uncle Jesse she recalled that her grandmother had said "he was the brightest of all her boys [but] had gotten into a fight with some toughs and rowdies and was beaten up [with] brass knuckles and so badly battered that he never recovered." To this explanation of Jesse's instability we must add those of Walt, who reported to the King's County Lunatic Asylum that his brother had injured his head in a fall from a ship's mast, and Jeff's, that Jesse had contracted syphilis from an Irish prostitute. To her version Miss Whitman added-as she had done regarding Edward-a personal, firsthand note: "I remember uncle Jesse and he was good and kind to me. He wasn't committed to the asylum until after we went to St. Louis. I am quite sure of it." Here she was simply mistaken; although we know that Jesse frequently rocked her cradle when she was an infant, he was forbidden to be near her after violently threatening her mother and sister six months after Miss Jessie was born, ${ }^{12}$ and he was institutionalized when she was only a year and a half old, three years before her family moved to Saint Louis. Whether 
this error, coupled with the barely more trustworthy account of those pushcart afternoons with Eddy when she could not have been more than three, should impugn the validity of Miss Whitman's explanations of the brothers' mental conditions, must remain a question. Everything she said about the old days in the Whitman household should be approached with caution, both because her memory of what she had experienced or been told so many years before was naturally less than perfect, and because of her tenacious determination to put the family in the best light. What can be safely said is that this interview contains the most forceful and specific testimony we have that the mental aberrations in Walt Whitman's family were not endogenous - as some scholars have perhaps too readily assumed-but rather the results of external factors.

Miss Jessie had interesting revelations to make about members of the family other than the two mentally troubled brothers. She recalled, for example, that her grandmother Whitman was downright pathological about household and bodily cleanliness: "If a neighbor came to call who was not considered tidy in her house-keeping, after she left grandma would get a damp cloth and wipe off the arms of her chair and where she had touched the door casing when she went. It grew to be a regular obsession. ..." One is tempted to contemplate what psychobiographers of Walt Whitman might make of such a point as this: the poet's own near-obsession with personal cleanliness, scrubbing and scouring himself in his almost ritualistic "lavatations," could be seen as influenced by his mother's abhorrence of unclean bodies; on the other hand, Walt's notorious disorderliness-living in the midst of a clutter of books, magazines, papers, bundles of letters and other accumulated detritus - is perhaps to be put down to rebellion against the anal propensities of the parent.

The interview gives us the only specifics we have, so far as I know, about the deaths of George Washington Whitman and his wife Lou, with whom Miss Jessie lived a good deal in her youth, first in Camden and later on their farm in Burlington, Vermont. She was at the farm in August 1892 when her aunt Lou died of a sudden appendicitis, and recalled for Fansler some bizarre circumstances: "Uncle George stopped in the bed-room trying to be of some help and Aunt Lou saw him and cried out 'Oh go away George, I don't care if I never see you again.' Poor Uncle George went downstairs broken hearted." Whether because of his broken heart she didn't say, but George wouldn't allow his wife's body to be put in a casket until after the funeral service, laying her out instead on the sofa with a shawl over her shoulders as if she were taking an afternoon nap. Jessie was also present in 1901 when George himself died, of blood poisoning, as she informed Fansler, the result of a cut inflicted by a loose brass plate on the door-pull of a restaurant in Brooklyn, where he had gone to collect rents from his several properties 
there. Those properties and other enterprises, along with his wife's money, had enabled George to accumulate a considerable estate, of which Miss Whitman was the sole heir.

Unfortunately no recollections of Walt Whitman from her young childhood emerged in Jessie's conversation with Fansler; the earliest memory we get is of his Saint Louis visit of several months when she was fifteen. She recalled, first, that Walt found sister Hattie's daily practice at the piano annoying, and that when she sat down to play, "He nearly always got up and left the house." To balance this image of Walt the curmudgeon, Miss Whitman pointed to a mahogany sideboard near where she and Fansler sat and related a pleasantly homey little scene involving the great poet and the Irish cook: "That's where Kate our cook used to put the big chocolate cakes she baked every few days, cakes with thick creamy chocolate frosting. Uncle Walt used to fairly gloat over them and he'd say, 'Kate, that cake looks too good to eat.' She used to reply, 'Go along with yez, you'll eat your share.' "13

Though there is plenty of evidence that Walt the admirer of chocolate cakes thoroughly enjoyed all the pleasures of the board, he was not always as appreciative of the food prepared for him as he was of Kate's confections. Miss Whitman had this story to tell of his irritating behavior when he was living in Camden with George and Lou-it probably dates from the early eighties, when Jessie would have been staying there on summer vacation:

Uncle Walt used to tax Aunt Lou's patience severely by coming downstairs at meal time, when she had prepared something he especially liked such as a broiled lamb chop, and put on his hat and leave the house, never saying where he was going or when he would return. Aunt Lou's lips would tighten and Tip, their little brown dog would get the lamb chop. More than once she said to me, 'Geniuses are not especially easy to live with.'

The accuracy of this recollection is confirmed by that of Amy Dowe, Aunt Lou's niece, who wrote in a memoir that "at dinner time Walt often either went for a walk or took a bath."14 Unfortunately we cannot be as certain of Jessie's accounts of two visits paid her uncle by Englishmen of widely different prominence.

Of Oscar Wilde's call she said that "the day was warm and bright and the men took their chairs out on the sidewalk in front of the house and put their feet up on one of the trees of the parkway." Walt Whitman may well have entertained some visitor in such an informal way-hence the colorful image remaining in Jessie's memory. But it was not Wilde, for his visit came in January 1882, when it was hardly "warm and bright" in Camden, but "awful cold," as Walt wrote to Harry Stafford; indeed, describing himself as an "invalid," he wrote to Mrs. George W. Childs on the day of Wilde's visit that he was "suffering an 
extra bad spell" and couldn't come out in "this weather" to dine with the Englishman at her invitation. ${ }^{15}$ Other accounts of the visit, including Wilde's own, say that the two poets talked in Walt's upstairs room, which was undoubtedly the case. Though she appears to have been confused about this aspect of the Wilde visit, we probably can trust Miss Jessie's recollection that straight-laced, conservative George Whitman, indignant at the scandalous Wilde having darkened his door, made Walt put out of sight the picture of himself that Wilde sent some days later: "I don't want people who come in thinking Oscar Wilde is any friend of mine or Louisa's," he declared.

Miss Whitman also had an engaging tale to tell of Sir Edwin Arnold's visit at 228 Mickle Street in 1889. She was not there herself, "but I understand," she told Fansler, "that Uncle Walt said just three words during the whole time . . . 'Ah, Ah, Ah,' just one 'ah' at irregular intervals. Uncle Walt used to pronounce it like we did as children when the doctor looked down our throat, but Walt could [make] it sound as though he were saying 'Quite so, my dear fellow;' or 'Your sentiments and mine are in perfect accord.' " If Horace Traubel's report is correct, Jessie's colorful story is again refuted by the poet's own words. Traubel records that within hours of Arnold's visit Whitman had told him that he had found his caller a "hearty, jovial, fine sample of a middle-aged man" whose only fault was being too flattering, and that they had "talked a great deal" for three quarters of an hour. ${ }^{16}$ According to Clara Barrus, Arnold wrote his own account of the visit, describing himself sitting for a long time beside "the most beautiful old man he ever beheld, Walt's shapely hand resting on his own, as they read together from Leaves of Grass, with 'sweet voiced' Mary Davis occasionally joining in the 'amiable chat,' while her handsome son stood in the doorway, and a big setter rested its head on Whitman's knee."17 As Barrus remarks, this excessive, saccharine scene is hard to countenance, and it may be, after all, that Miss Jessie's "understanding" of the meeting, whatever its source, is closer to the truth than Arnold's, maybe even closer than Traubel's: the aging and ailing poet may well have let the "hearty, jovial" and sycophantic younger man do most of the talking while he assented to the flattery with that " $\mathrm{Ah}$ " that meant "your sentiments and mine are in perfect accord."

Miss Whitman's affectionate good humor, evidenced in such stories as that about Walt and Sir Edwin, was counterpointed by her capacity for rancor, especially directed at those she thought guilty of misrepresenting the poet or showing insufficient respect for him and his memory. The chief target of her ire of this sort was Horace Traubel, whom Fansler also looked upon with a darkly jaundiced eye. Several of the later pages of the interview are given over to Fansler's own bill of indictment against Whitman's Boswell. Following John Burroughs and 
others, he accused Traubel of having put too many "hells and damns" into Walt's mouth, and of otherwise distorting, on occasion, what the poet said. More seriously, he also suspected Traubel and Thomas Harned of misusing their positions as literary executors for personal and monetary gain. These sentiments fanned the embers of Miss Whitman's smoldering resentment. When Fansler rehearsed a scene from Elizabeth Keller's (notoriously inaccurate) Walt Whitman in Mickle Street, in which Traubel, Harned and Richard Maurice Bucke are depicted clamorously packing up the poet's books and papers on the night before his burial, Jessie emphatically declared it to be true, adding "They were given his literary papers but were entitled to nothing else, and Aunt 'Lou' saw that they didn't get it." When George and Lou came in the house that night and noticed the books gone, Lou went upstairs "with fire in her eye, and made Traubel and Harned who were the only ones there unpack the boxes and remove every book and take them back down stairs, and she locked the bookcase and took the key with her." Miss Whitman's memory of this episode was not based on firsthand knowledge, for she was in Saint Louis when her uncle Walt died, ${ }^{18}$ but she had been at Mickle Street at Christmas, when he appeared to be near death, and she regaled Fansler with an account of the executors hastening to divvy up the poet's books at that time:

Aunt 'Lou' and I were admitted to the sick room to say a last good-by, because I never expected to see him alive after that, and I'm not positive that Aunt 'Lou' did either. When we came down stairs Uncle George went up for a few minutes. We waited down stairs in the sitting room and the three executors were there too over in the corner, by the bookcase. It was the first time I had ever seen Mr. Traubel, although I recognized Dr. Bucke from a picture up in Uncle Walt's room. They were looking over the books, some were valuable ones too, and although they were talking in a low tone both Aunt 'Lou' and I heard what was said. Harned seemed to be issuing orders. It was: 'You'll get this one Horace and this one; Dr. Bucke can have that and that, and I'll take such and such.' Doctor Bucke seemed to have some doubt as to the propriety of these proceedings. His voice was rather harsh and raspy, and he wanted everything to be 'done according to orderly process.' 19

Back in Burlington that night, Miss Whitman went on, she and her Aunt returned to the subject of the books: "only over my dead body will they get them," Lou vowed. "Being literary executors doesn't entitle them to Brother Walt's personal belongings." If Jessie's story of the locked bookcase is accurate, the indignant sister-in-law was as good as her word.

Again reacting to an opening provided by Fansler, when he asked whether there had been a regular accounting of Walt's estate from royalties of his works, Jessie replied, "As long as Uncle George lived there were regular remittances, but after his death they ceased permanently. I estimate that there are over $\$ 3,000.00$ due the estate in accu- 
mulated royalties that have not been paid." One wonders how Miss Whitman could have arrived at such a calculation, but the fact that she had it ready to hand as a barb to be driven at Traubel and Harned so long after both were dead testifies to the intensity of her prejudice against them. Her special bitterness regarding Traubel was nurtured by something that happened at the time he died, in 1919. The interview ends with her relating, in a state of high dudgeon, that when Traubel died his family sent her a telegram requesting he be buried in the remaining space in Whitman's tomb at Harleigh Cemetery. She being out of town, a "young scamp" of a Western Union boy signed her name to the register, and left the telegram in her mailbox, making it appear she had received but not responded to it. "I wonder what I would have done if they had gone ahead and buried 'poor dear Horace' [in Whitman's tomb] without my permission. I know I would have had quite a time getting him out, but out he would have come! I've heard it said that I'm to lie there when I'm dead. Well I'm not, that sepulchre has received its final occupant already."20

Of course Miss Whitman was not to be buried at Harleigh. She was released from the sanitarium to live with the Blome family for the last several years of her life. When they moved from Webster Groves, Missouri to Roswell, New Mexico in 1956, the aged lady went along. "We were afraid Miss Whitman would have difficulty making the long trip by car," Mrs. Blome remembered, "but she fared better than the rest of the family. We put a mattress in the back of the station wagon, and she rode gaily and comfortably during the strenuous journey. She loved New Mexico and adapted readily to the beautiful days and leisurely living." Walt Whitman's knee lived to ride in a speeding auto across the continent he had begun to sing so rapturously a hundred years earlier. When she died in Roswell on May 5, 1957, her body was returned to Saint Louis and buried in Belfontaine Cemetery beside those of her father, mother, and sister.

\section{Ohio Wesleyan University}

\section{NOTES}

1 Berthold and Price, eds., Dear Brother Walt (Kent, Ohio: Kent State University Press, 1984), xix.

2 Randall H. Waldron, ed., Mattie: The Letters of Martha Mitchell Whitman (New York: New York University Press, 1977), 1.

3 I am grateful to the Northwestern University library for permission to quote from the interview and other manuscript materials in the collection. Unless otherwise indicated, correspondence referred to in the essay is from this collection. 
4 Beyond scattered and fragmentary information in his letters to Jessie Whitman and in documents related to The Password Primeval, very little is known of Ralph Fansler. In a letter to Miss Whitman in March 1942 he declared himself to be beyond the fifty year age limit for military service; this, coupled with his apparently having been a student at Northwestern in 1912 (though there is no official record of his matriculation), suggests a birth date in the early to mid-eighteen nineties. At the time of the interview and at least until 1949 (according to telephone directories) he lived at 1546 Montclair Avenue, Detroit, and city census records list his occupation as Assistant Receiver at the Second National Bank.

There are in the Fansler Collection two lengthy but incomplete typescript versions of The Password Primeval, which the author referred to as an "imaginative narrative" of the life of Walt Whitman. It is indeed a highly fanciful work, often much more like fiction than biography. Though its imagined extrapolations from dependable biographical fact are sometimes entertainingly ingenious, its melodramatic and sentimental excesses, as well as its florid prose, frequently verge on the ludicrous. The work is dedicated to Jessie Whitman, whom Fansler appears to have trusted completely, declaring in his preface that she be taken as the ultimate authority on her uncle, even when her words refute all others. Miss Whitman in turn gave the book her enthusiastic imprimatur, according to a letter from Fansler to George Moreby Acklom, an editor at E. P. Dutton, who nevertheless declined to publish the work.

5 Fansler to Jessie Whitman, March 27, 1942.

6 Fansler to Franklin B. Snyder, President of Northwestern, September 25, 1942.

7 Letter dated March 1870; quoted with permission of the Library of Congress.

8 Letter dated March 6, 1888; quoted with permission of Ohio Wesleyan University.

9 An interesting item in the William Bayley Collection of Walt Whitman at Ohio Wesleyan is a large scrapbook, constructed by the poet from a world geography workbook, in which he saved an extensive miscellany of items related to the subject.

10 Miss Whitman's high opinion of Rogers' book helps explain her endorsement of the similarly fictionalized and romanticized Password Primeval.

11 See Clara Barrus, Whitman and Burroughs: Comrades (Boston: Houghton Mifflin, 1931), 254; and Katherine Molinoff, Some Notes on Whitman's Family (Brooklyn: The Comet Press, 1941), 11, 19. Barrus, two of whose letters to Miss Whitman are in the Fansler Collection, was grateful for and accepted her explanation of Edward's condition; Molinoff dismissed it as insufficient and said as much in her monograph, thereby raising the dander of her informant, who in a letter to Fansler complained of having been "taken in by that Molinoff woman."

12 Waldron, 33.

13 In a note accompanying his gift of the Jessie Whitman books and papers to Northwestern, Fansler wrote that the copy of Specimen Days that Walt had inscribed lovingly to Hattie and Jessie bore the fingerprints of Kate and the Irish cook, who had read the book "with great interest and delight." He does not suggest the prints were made with chocolate frosting, but it is pleasant to imagine Irish Kate in the kitchen, tasting the icing and licking her chocolatey fingers to turn the pages of Walt Whitman.

14 "A Child's Memories of the Whitmans," reprinted in part in Edwin Haviland Miller, "Amy Dowe and Walt Whitman," Walt Whitman Review 13 (September 1967), 76.

15 Walt Whitman, The Correspondence, ed. Edwin Haviland Miller (New York: New 
York University Press, 1964), 3:264, 263.

16 With Walt Whitman in Camden, ed. Gertrude Traubel (Carbondale: Southern Illinois University Press, 1964), 5:506, 510.

17 Whitman and Burroughs: Comrades, 262.

18 Walt Whitman, The Correspondence, ed. Edwin Haviland Miller (New York: New York University Press, 1969), 5:277.

19. A few minutes earlier Miss Whitman had said that she liked Bucke best of the three literary executors, a sentiment with which Fansler-who thought Cosmic Consciousness "the greatest book ever written" after Leaves of Grass-wholeheartedly agreed.

$20 \mathrm{Had}$ Fansler had his way, such would not have been the case: in a letter to Miss Whitman shortly after the interview he wrote of his wish to bring about, with her approval and using anticipated profits from The Password Primeval, the reinterment of brother Jesse in Walt's tomb, thus "giving full notice to the world that Jesse Whitman has come home."

21 Waldron, 96. 